\title{
THE MIDDLE COLOR: A HISTORY OF A PROBLEM IN THIRTEENTH CENTURY OXFORD COMMENTARIES ON DE SENSU ET SENSATO**
}

Keywords: Natural Philosophy, Medieval Aristotelianism, Commentaries on De sensu et sensato, Adam of Buckfield, Geoffrey of Aspall

* Monika Mansfeld-PhD, Assistant Professor in the Institute of Philosophy, University of Łódź, Poland, as well as a Visiting Scholar at the University of Oxford. She received her $\mathrm{PhD}$ in 2015 from the University of Silesia and has published several articles and book chapters on the history of medieval philosophy. Research interests: manuscript studies, natural philosophy, metaphysics, Aristotelianism in the Later Middle Ages.

Address for correspondence: University of Łódź, Faculty of Philosophy and History, Institute of Philosophy, Lindleya 3/5, 90-131 Łódź. E-mail: morginess@gmail.com.

** This paper is a result of research financed from the grant of the Polish National Agency for Academic Exchange (NAWA), Bekker's Programme: The Theory of Sensual Perception in the 13th Century Oxford (PPN/BEK/2019/1/00011). I wish to thank Prof. Marek Gensler for numerous discussions we had on the topic of this paper and for correcting my English. Last but not least my deepest gratitude goes to Monika Michałowska, Richardo Fedriga and Costatino Marmo, the editors of this volume, and the anonymous reviewers for helping to improve it both doctrinally and stylistically. 


\section{Introduction}

Aristotle did not write any work devoted exclusively to color. Passages in which he discusses the theory of color and color perception are dispersed in several of his writings, including De anima, Meteorologica, some works on zoology; in the most elaborate form, it is presented in De sensu et sensato. ${ }^{1}$ All these works became available to Western scholars in Latin translations between the late twelfth and mid-thirteenth centuries at the latest. Aristotle's teaching on color was supplemented with other newly translated treatises on perspective, such as Euclid's Optica and Catoptrica (De speculis), Alkindi's De aspectibus, and Alhazen's De aspectibus (also known as Perspectiva). All of them soon became the basis for scholastic works on the same subject, e.g., by Roger Bacon and John Pecham. Although their approach to the problem of visual perception was far from the Aristotelian one, they were sometimes utilized by those willing to comment on Aristotle's views on color by employing a mathematical model based primarily on the rules of refraction and reflexion. The group of secondary texts often included the Pseudo-Aristotelian De coloribus, a treatise written by an anonymous scholar from the Peripatetic school in the third century BC. ${ }^{2}$ Because some of its medieval readers were not entirely convinced that the theory of color presented in De coloribus is fully compatible with Aristotle's views on the issue, it was used sparingly when commenting on the latter. ${ }^{3}$

Other source texts on visual perception notwithstanding, De sensu et sensato remained the most important text for the thirteenth century scholars who discussed Aristotle's theory of color in general and the problem of the so-called middle color (color medius), the main subject of this paper, in particular. The scholastics' problems with the notion of the middle color can be divided into two groups. First, there are strictly philosophical problems, such as establishing the number of colors between white and black and whether there is a middle color par excellence, i.e., the one in which the

1 For more on the sources of Aristotle's theory of color, see Pastoureau, 2018, pp. 192-193.

2 Dod, 2008, pp. 49, 85.

3 E.g., Galfridus de Aspall, Quaestiones in De sensu et sensato Aristotelis, q. 57, Utrum elementa sint colorata and q. 59, Utrum quattuor qualitates primae sint principia coloris. 
proportion of the extremes is even etc. ${ }^{4}$ Second, there are the philological ones, which result from the very nature of Latin color terminology available at the time. When commenting on Aristotle's theory of color, medieval commentators of De sensu et sensato had to deal with lamentably imprecise color terms, which, to make matters worse, did not have fixed meanings yet. Those terms could refer not only to several "modern" colors at a time but also included some qualities other than color, such as luminosity, saturation, smoothness of the object's surface and many more. ${ }^{5}$

This paper aims to reconstruct the earliest attempts to comprehend Aristotle's concept of the middle color undertaken by the thirteenth century Oxford commentators of De sensu et sensato. It is focused on the relationship between philological choices made by the first translator of the treatise and the philosophical interpretations and questions triggered by them. My interest is restricted exclusively to Oxford scholars of the thirteenth century for several reasons. First, the earliest stage of De sensu et sensato's reception in the Latin world is the time in which the problem of the middle color was especially significant. Second, the commentaries' authors wrote almost exclusively literal expositions, whose main objective was an understanding of the text. They probably formed a group of scholars discussing the same problems with one another rather than referring to commentaries written in other academic centres. This is visible in the doctrinal content of their works: there is a number of references to their colleagues' works but almost no references to any Parisian commentaries on De sensu et sensato, not even to Bacon's. Third, they share references to other works instead, such as medical texts and even art manuals, and make extensive use of those non-philosophical works, which makes their solutions to the middle color problem even more interesting.

4 The term "the middle color," as medieval scholars understood it, was equivocal, for it might have stood both for any color between white and black and for the middle color par excellence between these two extremes. As we shall see, this equivocation caused some problems of interpretation for the earliest commentators of De sensu et sensato.

5 For some examples of difficulties concerning studying Latin color terminology, see Pastoureau, 2018, pp. 25-27. 


\section{The First Translation of De sensu et sensato}

Roger Bacon, who is believed to be the first Latin commentator of Aristotle's De sensu et sensato, is well known for his critical attitude towards translations of Aristotle's works on natural philosophy. He complained about numerous passages he found ambiguous, nonsensical or contradictory to statements that he had found in other writings by Stagirite, and fiercely attacked translators for their apparent lack of skill. ${ }^{6} \mathrm{He}$ saw them as ignorant, because they restricted themselves to word-for-word translation, disregarding the specificity of Latin syntax, and abused transliteration of Greek terms instead of looking for their Latin counterparts. ${ }^{7} \mathrm{He}$ also frequently criticized their stylistic choices. Reading Bacon's scathing remarks, one may wonder whether the translations were really so bad. After a closer look at the first Latin translation of De sensu et sensato, the so-called translatio vetus, one must but agree.

Very little is known about De sensu et sensato's translator and the date of his work. Griet Galle compared the lexicographical and stylistic features characteristic of this anonymous translation with the ones from all other early translations of Aristotle. Her aim was to establish whether the translation of De sensu et sensato shares any similarities with other translations and, if so, whether its translator could be identified with anyone we know. Her conclusion was negative: De sensu et sensato differs stylistically from other works so much that it should be considered unique. ${ }^{8}$ It must have been that particular translator's only attempt to render Aristotle's text into Latin. There is no doubt he had little knowledge of how to do it. His translation is full of mistakes: for instance, David Bloch noticed that he often used the same case in Latin as in Greek, even when it was inappropriate in the

${ }^{6}$ For the most elaborate critiques of bad translations, found in the third part of his Opus Maius, which is devoted to theory of language and translation, see Roger Bacon, Opus Maius (ed. Bridges, 1897, pp. 66-96). Some remarks on the consequences of bad translations of Aristotle's works on natural philosophy are also present in the second part of the same work. Cf. Roger Bacon, Opus Maius (ed. Bridges, 1897, pp. 38-41). He also wrote a Greek grammar for Latin speakers. Cf. Roger Bacon, Grammatica Graeca (ed. Nolan, Hirsch, 1902).

7 Cf. Parkhurst, 1990, pp. 159-161.

${ }^{8}$ Cf. Galle, 2008b, pp. 105-108, 136. 
former, and introduced some phrases that were meaningless in Latin, which may indicate that the translator was Greek himself. ${ }^{9}$

The terminus ante quem of the translation is 1232 , when the references to De sensu et sensato appear in the anonymous De potentiis animae et obiectis. ${ }^{10}$ Some time later, probably in the early $1240 \mathrm{~s}$, it was commented upon by Roger Bacon in Paris. ${ }^{11}$ There is, however, no consensus concerning its terminus a quo. Some scholars suggest that the translation could have been done by the second half of the twelfth century. ${ }^{12}$ According to them, its poor early reception may have been caused by the scholars' focus on other newly-translated works in psychology and physiology or by problems with its understanding without the help of other works on the subject, such as Averroes commentaries, which were not translated until the 1230s. ${ }^{13}$ Some other researchers support a hypothesis that it was completed no sooner than the beginning of the thirteenth century, pointing to the fact that none out of the 92 known manuscripts containing the translatio vetus dates from the twelfth century and there is no testimony of its knowledge in the authors of that period. ${ }^{14}$

\section{Problems with Aristotle's Theory of Color}

No matter when it happened, the Western scholars who laid their hands on this translation had to struggle with the artless style of Aristotle made worse by a poor translation. The problems they encountered are evident especially in the theory of color. As they could learn from De sensu et sensato, Aristotle claims that there are two so-called extreme colors, sc. black and white, and a number of so-called middle colors, such as red and green, which are somehow derived from the first two. The specific terminology that Aristotle employs when talking about colors reflects his opinion that colors form a sequence which has white and black at its extreme points and

\footnotetext{
9 More information about this hypothesis and linguistic problems in the translation of De sensu et sensato can be found in Bloch, 2008, p. 87.

${ }^{10}$ Galle, 2008b, p. 108; cf. Callus, 1952, pp. 131-170.

${ }^{11}$ Cf. Roger Bacon, Liber De sensu et sensato (ed. Steele, 1937).

12 Cf. Raizman-Kedar, 2007, p. 372.

${ }^{13}$ Cf. Galle, 2008b, p. 107.

14 Galle, 2008b, p. 107; cf. Galle, 2008a, p. 198.
} 
five middle colors placed at intervals along it. ${ }^{15}$ Each of the middle colors is fixed at a point between the extremes according to a specific ratio of whiteness to blackness proper to it. ${ }^{16}$ Then, Aristotle enumerates the middle colors. The translatio vetus runs as follows:

Fere enim equales et humorum species et colorum sunt; septem enim utrorumque species quis ponat; quare rationabiliter lividum album quid esse. Sequitur enim flavum quidem albi esse, quemadmodum unctuosum est dulcis, puniceum vero et alurgon et viride et kianos in medio albi et nigri, alii vero inter istos. ${ }^{17}$

For the thirteenth century Oxford scholars this passage turned out to be a veritable puzzle. On the whole, there were three problems with which they had to struggle. First, they did not know what colors or hues hid behind the transliterated Greek terms kianos and alurgon. Scholars who were not as fortunate as Roger Bacon with his fluent Greek ${ }^{18}$ were forced to guess their meanings from the context. Second, in his text, Aristotle actually enumerates eight colors rather than seven; what should be done about the extra one? Third, if Aristotle claims that there are seven colors in total, there is an implicit problem concerning the middle color par excellence, sc. the one in which the ratio of whiteness to blackness is even. To the best of my knowledge, the last problem, which was genuinely philosophical, was new at the time and attracted commentators' attention for at least a few decades until its doctrinal relevance finally vanished.

${ }_{15}$ Cf. Aristoteles, De sensu et sensato, 3, 439b14-440b26 (ed. Peeters, TAGL.13.1, ALDatabase).

16 Parkhurst, 1990, pp. 158-159.

${ }_{17}$ Cf. Aristoteles, De sensu et sensato, 4, 442a19-25 (ed. Peeters, TAGL.13.1, ALDatabase).

${ }_{18}$ I do not include Roger Bacon in my paper for several reasons. First, according to Robert Steele, who was the editor of the single manuscript containing the commentary on De sensu et sensato, it bears no author's name and was ascribed to Bacon because of some doctrinal similarities to his other works. Almost nothing is known about when and where it was written, but the most probable place of its origin is Paris. Finally, from the doctrinal point of view, his commentary had very limited, if any, influence on upon Oxford commentators in the thirteenth century. For more information on the authorship and the description of the manuscript, see Steele, 1937, pp. v-vii, xi-xii. 


\section{Oxford Commentators of De sensu et sensato in the Thirteenth Century}

The first scholar to address those problems in Oxford was Adam of Buckfield. ${ }^{19} \mathrm{He}$ was among the earliest commentators of Aristotle's works on natural philosophy there. The first mention of him in Oxford is 1238, when he received the king's exceptional permission to temporarily leave the university regardless of the prohibitions imposed on scholars after the attack on the papal legate. ${ }^{20}$ The break in his studies, however, could not have lasted long, for we know that he obtained his MA degree by $1243^{21}$ and then continued teaching at the Faculty of Arts. There, he soon became a man of a high reputation and eventually attracted the attention of Adam Marsh, who recommended him to Robert Grosseteste as a good candidate for the rector of the church of Eure (Evere, Eure), now Iver in Buckinghamshire, not far from Heathrow Airport. ${ }^{22}$ As a result, Adam of Buckfield, who was presumably a master of theology at that time, ${ }^{23}$ got the position. Some time later, he was also made a canon and prebendary of Lincoln cathedral. ${ }^{24}$ Moving to Lincoln apparently ended his teaching career in Oxford, which spanned about 15 years in the $1230 \mathrm{~s}$ and 1240 s. In some later documents, he appears as a collector of papal tithes in Lincoln, an executor of Richard of Munfichet's

${ }^{19}$ His surname was written in so many ways (Bocfeld, Butrefeld, Buchphiz, Bonefeno, Bouchermefort, Bochesmefore, etc.) and there were so many works ascribed to him that some twentieth-century scholars put forward a hypothesis there were actually two Adams: an Englishman, who was called Adam of Buckfield (Bocfeld) and a Frenchman, namely Adam of Bouchemerfort. This hypothesis, however, was soon abandoned and a general agreement was reached. For more details of this debate, see Thomson, 1944, pp. 55-57.

${ }^{20}$ Emden, 1957, p. 297. There was an attack upon the papal legate on his retinue at Oseney Abbey in Oxford by a number of clerks from the University of Oxford. The legate's brother was killed and the legate himself was forced to flee for his life. As a result, the members of the university were forbidden to enter or leave Oxford under the king's interdict.

21 Emden, 1957, p. 297.

${ }^{22}$ Cf. Brewer, 1858, p. 165. Marsh called Adam of Buckfield a scholar of "commendable excellence of manners, of divine eloquence and skills in human letters."

${ }^{23}$ Cf. Russell, 1936, p. 3.

${ }^{24}$ Cf. Noone, 1992, p. 308. 
will, and an administrator of some church estates. ${ }^{25}$ He died between 1278 and $1294 .{ }^{26}$

Adam of Buckfield was a prolific writer. Although he composed, presumably for didactic purposes, literal commentaries on the whole corpus Aristotelicum vetustius, ${ }^{27}$ his main philosophical interest lay in Aristotle's works on natural philosophy. ${ }^{28}$ In his commentaries, he offered a very detailed system of structural divisions and subdivisions of the commented text (divisio textus) followed by explanations or paraphrases of problematic passages. Many of Buckfield's writings are preserved in more than one redaction. This is also the case of his exposition of De sensu et sensato. It used to be considered to have two redactions: the first one, found in six manuscripts (Cambridge, Lisbon, Madrid, Milan, Oxford, and Philadelphia), ${ }^{29}$ was believed to be authentic, while the other, preserved in three manuscripts (Erfurt, London, and Vatican), ${ }^{30}$ was treated as spurious by some scholars. More recently, Griet Galle modified this division. First, she singled out the Lisbon manuscript, formerly put in the first redaction, arguing that it should be considered a separate, third redaction. She also suggested that the first redaction should cover only four manuscripts (Madrid, Milan, Oxford, and Philadelphia). The Cambridge manuscript and yet another manuscript from Erfurt are supposed to contain some anonymous abbreviations of this text. ${ }^{31}$ In her opinion, the authenticity of all texts beside the first redaction

${ }_{25}$ Cf. Russell, 1936, p. 3.

26 Emden, 1957, p. 297.

27 Callus, 1943, pp. 29-30.

${ }^{28}$ As for now, we know of more than 60 manuscripts containing some of his works spread throughout the European and North American libraries. Cf. Lohr, 2013, pp. 3-9; Lohr, 1967, pp. 317-23.

${ }^{29}$ Cambridge, Gonville and Caius College 506 (384), ff. 282r-293r (C); Lisboa, Biblioteca Nacional, Alcobaça 382, ff. 126va-141rb (Li); Madrid, Biblioteca Nacional de España 3314, ff. 100r-110v (Ma); Milano, Biblioteca Ambrosiana H.105 inf., ff. 1r-18r (Mi); Oxford, Balliol Coll. 313, f. 132r-144v (O); Philadelphia, Free Library, Lewis European 53, ff. 52ra-57vb (Phi).

${ }^{30}$ Erfurt, Universitätsbibliothek, Dep. Ampl. F. 318, ff. 150r-161r(E); London, Wellcome Hist. Med. Libr. 3, ff. 53v-60r (W); Vaticano, Biblioteca Apostolica Vaticana, Vat. lat. 5988, ff. 34ra-41va (V).

${ }^{31}$ Cambridge, Gonville and Caius College 506 (384), ff. 282r-293r (C); Erfurt, Universitätsbibliothek, q. 312, ff. 69va-73vb $\left(\mathrm{E}_{2}\right)$. 
is uncertain. ${ }^{32}$ My preliminary research of the passages devoted to the theory of colors complies with Galle's findings. I have compared samples from all three redactions with one another; they demonstrate differences which are so numerous and so significant that it is hardly possible that texts have a common source.

It is interesting to note that the ideas found in the so-called second redaction seem close to those of yet another thirteenth-century English scholar, Adam of Whitby, an otherwise obscure person who composed several commentaries on Aristotle's works and might have been somehow related to Adam "de Withebi", who was sheriff of London in $1210 .{ }^{33}$ It seems highly probable that he was a colleague, maybe a little younger, of Adam of Buckfield in Oxford, for they evidently share the same philosophical background and commenting style. ${ }^{34}$ Even more interesting but truly challenging is the analysis of doctrinal contents of the third redaction of the commentary, because the quality of the text transmitted by its only copy is so poor that it hardly makes any sense at all. ${ }^{35}$ Nevertheless, the fragments I have deciphered so far seem to support the hypothesis that it is closer to the first redaction than to the second one.

For these reasons, my paper considers only the first redaction, as established by Galle to be the genuine commentary on De sensu et sensato by Adam of Buckfield. My interpretation of its most confusing passages is complemented with glosses from the anonymous Cambridge abbreviation of this

${ }^{32}$ Cf. Galle, 2008a, pp. 204-208. The defenders of the authenticity of all redactions ascribed to Adam of Buckfield explain that the differences support the hypothesis that the author was dissatisfied with the original results of his commentary work and rewrote some of his lectures several times. Cf. Thomson, 1958, p. 25.

${ }^{33}$ Cf. Russell, 1936, p. 10.

34 We know of three manuscripts containing Adam of Whitby's commentary on De sensu et sensato: München, Staatsbibliothek, Clm 14522, ff. 149rb-154vb (M); Paris, BN, lat. 16149, ff. 62ra-67ra (P); and Firenze, Biblioteca Nazionale Centrale, Conv. Soppr. G 3 464, ff. 73vb-78ra (Fi). Cf. Lohr, 1967, p. 324; cf. Weijers, 1994, p. 31; cf. Köhler, 2017, p. 52. In my paper, I will take into account only the last copy, namely Fi, because M lacks the whole passage on the theory of colors (it suddenly breaks in the middle of the commentary and the continuation does not cover these considerations) and I did not have access to P.

35 The bad quality of Li has already been noticed by Galle, who doubts whether it is possible to read it without the editor's far-reaching intervention in the text and multiple conjectures. Cf. Galle, 2008a, pp. 207-208. 
redaction. The second, unauthentic redaction of Buckfield's commentary and the exposition by Adam of Whitby are analyzed together as they seem to complement one another doctrinally. The third redaction is used in fragments only but, as we shall see, it presents some ideas that seem to be unrelated to any other known commentaries on De sensu et sensato from that period and, for that reason, offers some unique insights. On the basis of these commentaries, I present a survey of the opinions of Oxford scholars on the idea of the middle color in the first period of the reception of De sensu et sensato (ca. 1230-1245). The picture is completed with an analysis of a question-commentary by Geoffrey of Aspall, who wrote his commentary in the late 1250 s or at the beginning of the 1260s. Aspall, who was a generation younger than Adam of Buckfield, is sometimes considered as a student of the latter. His commentary was considered the most developed and elaborate work on the topic in his times. At the same time, it was the last interpretation of the De sensu et sensato before William of Moerbeke revised the translatio vetus. ${ }^{36}$

\section{Oxford Interpretations of the Problem of the Middle Color}

In the first redaction of the exposition on De sensu et sensato, Adam of Buckfield states that there are two extreme and five notable (notabiles) middle colors. All other ones, the so-called "less notable colors," can be easily reduced to the notable ones; for instance, crimson, burgundy and carmine can be reduced to red, whereas teal and emerald to green. Such a division makes one think of the "notable" colors as some general categories and the

36 On the dating of Aspall's professional activity, see Geoffrey of Aspall, Questions on Aristotle's Physics (ed. Donati, Trifogli, 2017, p. xi). Galfridus de Aspall, Quaestiones in De sensu et sensato Aristotelis, q. 68, Utrum colores medii sint finiti an infiniti, Oxford, Merton College Library, 272, f. 273va (M); Todi, Biblioteca Comunale Lorenzo Leoni, 15, f. $117 \mathrm{ra}-\mathrm{rb}(\mathrm{T})$. There are two more copies of the text, but Cambridge, Gonville and Caius 509/386, ff. 287-302 (C) breaks off in the middle of q. 55 and I was not able to consult Oxford, New College 285, ff. 164-189 (N). Galfridus de Aspall, Quaestiones in De sensu et sensato Aristotelis, q. 69, Utrum visus posset ab omnibus coloribus immutari, M, ff. 273vb-274ra; T, f. 117rbv. 
"less notable colors" as particular hues. Following Averroes, ${ }^{37}$ Buckfield claims that there are precisely seven notable colors (two extreme and five middle ones); their hues which occur in nature, however, are infinite in number. ${ }^{38}$ The five notable middle colors form a sequence in which the ratio between the extremes gradually changes in favour of black in the subsequent middle colors until white is completely eliminated in black itself. According to Buckfield, there is a color in which the proportion between white and black is perfectly even. This color should be then placed right in the middle of the sequence. Yet he does not point explicitly to any particular color; instead, he makes a reference to an ongoing argument between scholars who favour red and those who favour green. ${ }^{39}$ Regrettably, he does not cite the reasons they give in favor of their choices. Still, as we can see in subsequent passages, Buckfield seems to have tacitly accepted purple or deep red (puniceus) as the middle color sensu stricto.

Another problem is the color terminology. Buckfield first enumerates the colors he found in the translatio vetus of De sensu et sensato so that he can analyze them later.

Similiter etiam enumerat colores medios quinque ${ }^{40}$ scilicet lividum sive flavum, puniceum, alurgon, ${ }^{41}$ viride et kianos ${ }^{42}$ qui sunt medii inter

37 Averroes, In De sensu et sensato (ed. Shields, Blumberg, 1949, p. 18): "Et quia colores fiunt ex albo et nigro secundum magis et minus et diversantur in hoc diversitate infinita secundum materiam, ideo fuit necesse ut colores sint infiniti in natura."

38 Adam de Buckfield, Expositio in De sensu et sensato Aristotelis, Red. I, Ma, f. 105rb; Mi, f. 10ra-rb; Ba, f. 139ra; Phi, ff. 54rb-55ra: "Consequenter, cum dicit solus igitur, in speciali determinat numerum et multitudinem saporum iuxta numerum et multitudinem colorum. Et est intentio illius partis quod sapores non excedunt numerum septenarum secundum speciem sicut nec colores [...]. Et isti sunt sapores notabiles sub quibus comprehenduntur omnes alii sapores qui sunt secundum naturam, ut praehabitum est a Commentatore, qui sunt infiniti. Sic igitur species saporum notabilium sunt septem, sicut et species colorum."

39 Adam de Buckfield, Expositio in De sensu et sensato Aristotelis, Red. I, Ma, f. 105rb; Mi, f. 10rb; Ba, f. 139ra; Phi, f. 55ra: "Quis tamen sit color simpliciter medius aut sapor simpliciter medius inter extrema non est certum, quia diversi diversimode sentiunt in hoc. Rubeum enim secundum quosdam est medium simpliciter inter colores extremos, secundum quosdam autem viride."

40 medios quinque] inv. Ma

41 alurgon] alurgen MaPhi albuggon $\mathrm{Mi}$

42 kianos] quianos BaMi 
album et nigrum. Et forte intelligit per alurgon ${ }^{43}$ colorem subpuniceum qui magis habet de albo quam de nigro, per kianos ${ }^{44}$ autem colorem medium inter rubeum et nigrum, accedentem magis ad nigredinem. ${ }^{45}$

It seems that the Greek terms he found in the translatio vetus confused Adam greatly ${ }^{46}$ for he tried to figure out what colors hid behind the enigmatic names. His way of reasoning looks as follows: if the very middle color divides the sequence into two even groups, there must be two middle colors closer to white and two middle ones closer to black. Consequently, he places lividum or flavum and alurgon in the first group and viride and kianos in the other. Thus, alurgon has to be darker than white and brighter than purple (the actual middle color sensu stricto) while kianos has to be darker than purple and brighter than black.

The actual hue of kianos remains a mystery. In the description provided by Buckfield, only one thing is certain: it is a dark color other than green (viride). ${ }^{47}$ By contrast, alurgon is more precisely identified as a color that is "somewhat purple" or "less than purple" (subpuniceus), which suggests that Buckfield believed it to be light red, orange or, perhaps, pink. His guess, however original it may be, is nevertheless inconsistent with how the term was usually rendered in Latin. As we can read in the Latin translations of Aristotle's Meteorology and Pseudo-Aristotelian De coloribus, alurgon was translated as purpureus, puniceus or muriceus, all meaning deep red or purple. ${ }^{48}$ It is worth noting that the text of De sensu et sensato itself prevented Adam of Buckfield from simply identifying alurgon with red: this place was already occupied by purpureus and rubeus.

Apart from problems with guessing the meaning of Greek terms used in the translatio vetus, Adam of Buckfield encountered yet another

43 alurgon] alurgen MaPhi alburgon Mi

44 per kianos] perlixanos (!) Mi

${ }^{45}$ Adam de Buckfield, Expositio in De sensu et sensato Aristotelis, Red. I, Ba, f. 139ra; Ma, f. 105rb; Mi, f. 10rb; Phi, f. 55ra.

46 Judging from the variations of writing alurgon (albuggon, albugon, alurgen, aluggon) and kianos (quiannos, quianos, kiannos, kyanos) in the manuscripts we possess, the scribes who copied his text must have shared his confusion.

${ }^{47}$ Of course, my translation of viride as green is a simplification as well. In fact, this color covered various hues, "since in the whole of Latin tradition, one can find viride associated with grass, skies, parrots, sea, trees.” Eco, 1985, pp. 157-158.

48 Beullens, 2014, p. 179. 
problem with Aristotle's list of colors. He noticed that Aristotle set the number of colors as seven but enumerated more colors (eight), which made his list look suspicious. Our commentator tried to get out of the problem by identifying two colors, namely flavum and lividum, with one another, even though Aristotle himself probably thought them to be distinct. The word $f l a-$ vus employed by the first translator of De sensu et sensato was an unfortunate choice, since it is equivocal. Modern dictionaries usually explain flavus as standing for the whole category of "yellow". Its vagueness is manifested by the examples conventionally given by authors writing in Latin, such as fair hair, the faint beards of adolescent males, turbid water and rivers, the underside of olive trees, sand, honey, wax, fields, golden coins and dishes, clearly not all of them being yellow. ${ }^{49}$ What they all seem to have in common is that the term flavus does not designate any particular color of the spectrum but indicates some other features that are often associated with yellow objects, namely "fair", "delicate", "bright", "fresh" or "shiny".

Adam of Buckfield must have been aware of the equivocality of the term flavus, because in his text he tried to nail its meaning by pairing it with yet another term, which he considered synonymous to it, namely lividus. This was rather unfortunate, because lividus means bluish-grey. In a figurative sense, it is usually associated with negative feelings and actions, especially with envy, malice and death. ${ }^{50}$ As a result, we do not know how Buckfield actually envisaged Aristotle's sequence of colors. Moreover, it is difficult to apply simultaneously bothflavus and lividus to the same object; for instance, somebody's face being ruddy and livid at the same time is very hard to imagine. In turn, if we try to interpret Buckfield's position suggesting that he wanted to use these two terms in sensu diviso, we have to admit that there are not seven notable colors but eight. This makes the discussion on the middle color par excellence completely unintelligible-if the number of colors is even, there cannot be such a color.

Buckfield left this problem unsolved. There are some texts, however, viz. abbreviations inspired by his commentary preserved in Erfurt ${ }^{51}$ and Cambridge, ${ }^{52}$ which make it possible to search for some interpretative

\footnotetext{
${ }^{49}$ Cf. Bradley, 2009, pp. 3-7.

${ }^{50}$ Cf. Lewis, Short, 1879, p. 1073.

${ }^{51}$ For the description of this codex, see Wood, 2003, pp. 33-41.

${ }^{52}$ Cambridge, Gonville and Caius Coll. 384(506), ff. 282r-293r.
} 
hints. The first one repeats Buckfield's way of reasoning and solutions without adding anything new but the other provides us with an extra explanation concerning the identification of flavum with lividum. A marginal gloss informs us that the terms were treated as synonyms by Aristotle himself, because they both designate colors closest to white. ${ }^{53}$ This last remark gives us some idea of how to interpret Buckfield's proposition: he calls a color flavum or lividum, because from his point of view it is not so important which hue of the spectrum it actually designates. He simply locates the place it occupies in the sequence between white and black. It can be literally any hue in which whiteness predominates; we can actually call it whatever name we want—bluish, yellow, light pink or greyish — as long as the designate is a sufficiently bright and unsaturated color.

The spurious second redaction of Adam of Buckfield's commentary on De sensu et sensato contains one more remark on the identification of $\mathrm{fla}$ vum with lividum which may be interesting to us. Its author explains that although both terms designate colors very close to white, they nevertheless cannot be identified just as some shades of white; they are no doubt distinct colors. The need to stress it may seem odd at first, but the author had a good reason to do so. This was because he believed that in Aristotle there is a symmetry between the number of colors and tastes, which would otherwise be at risk, since, according to him, some physicians added an extra taste to Aristotle's list of seven, namely "tasteless" (insipidum). ${ }^{54}$ Our commentator disregarded "tasteless" as a distinct taste, yet called it "almost" (fere) a taste. He must have foreseen that if he uses an argument of this kind with respect to taste, somebody else can reverse it and aim it at the distinction of flavum and lividum: if they are so close to white that are "almost white", they can

${ }^{53} \mathrm{Cf}$. Anonymous, Commentarium in De sensu et sensato, Cambridge, Gonville and Caius Coll. 384(506), in marg. dex. 287r: "Nota quod idem intelligit per lividum et flavum et quod immediate sequitur album."

${ }^{54}$ For more on the notion of "tasteless" in medical text, see e.g., Anonymus, Problemata, Corpus Christi College, Oxford, 233, ff. 21r-31v, q. 30 (ed. Lawn, 1973, p. 338): "Cur quedam sapore carent fut dicantur, $†$ ut aqua et similia. Responsio. Eorum que sapore carent quedam sunt simplicia ut aqua, quedam composita ut albumen ovi. Simplicia carent sapore quia sicut invenitur in Dietis, simplicia non agunt in compositis quod composita in compositis. Cum ergo simplicia adhibemus lingue, quia non sunt ei affinia lingua non sic attrahit ea ut passio fiat in ipsa, per quam immutata saporis habeat discretionem. Licet ergo insipida simplicia saporem teneant, dum de eis non habetur discretio iudicantur insipida." 
be identified with it. He argues that the analogy is superficial here. The situation with flavum, lividum and white reminds him more of the relationship between sweet and fatty tastes, which are distinct registers beyond doubt but in some aspects seem alike (for instance, both sweet and fatty foods are usually pleasant). ${ }^{55}$

Moreover, the disagreement between philosophers and physicians of those times seems to go deeper than that. Adam of Whitby notes that some authors of medical writings suggest that there are nine colors rather than seven Aristotelian ones. Regrettably, though expectedly, he does not provide us with any further information on this topic, so we are unable say which particular nine colors they have in mind, let alone whose opinions he refers to. ${ }^{56}$ Adam of Whitby concludes that, contrary to physicians, philosophers used to accept Aristotle's sequence of colors with two extreme and five middle ones. ${ }^{57}$ Unfortunately, what he says is only an empty framework, for

${ }^{55}$ Cf. Ps.-Adam de Buckfield, Expositio in De sensu et sensato Aristotelis, Red. II, V, f. 37ra-rb; E, ff. 155vb-156ra; W, f. 56va: "Consequenter determinat numerum istarum specierum intendens quod septem sunt species saporum sicut et colorum, scilicet duae extremae et quinque mediae. [...] Dicit tamen in littera 'fere' propter saporem insipidum de quo non fecit mentionem quem ponunt medici esse saporem. Non enim est insipidus sapor proprie sapor sed potius privatio saporis. Sunt igitur album et nigrum extrema in colore. Lividum autem sive flavum, licet sit medius color, tamen propter sui vicinitatem ad album non ponunt in numero cum albo, sicut nec pinguis sapor in dulci."

${ }^{56}$ Cf. Adam de Whitby, Commentarium in De sensu et sensato Aristotelis, Fi, f. 76ra: "Secundum autem medicos est iste numerus in novenario, et hoc quia ipsi numerant duos medios inter extremos et aequidistantem: primum medium plus accedens ad ipsos extremos." Curiously enough, Roger Bacon in his commentary on De sensu et sensato states that there are nine colors with red as the middle color par excellence. I doubt, however, that Adam of Whitby had this particular work in mind here, because he would have probably not classified it as medical writing. Cf. Parkhurst, 1990, p. 164.

57 A similar enumeration of seven colors occurs in the treatise by Jehan le Begue written almost two centuries later. What is interesting for our current considerations, he claims that the number of colors is correlated with the number of planets. Cf. Jehan le Begue, Tabula de Vocabulis Sinonimis et Equivocis Colorum (ed. Merrifield, 1849, p. 23): "Color similiter est vocabulum universale pro omnibus coloribus, et Graece croma dicitur, et quot sunt planetae, tot sunt colores, videlicet septem, qui sunt primo duo extremi, albus et niger, et reliqui quinque qui intermedii dicuntur, videlicet caelestis seu lazurius, rubeus, croceus seu aureus, viridis, et sanguineus seu purpureus aut violetus vel fulvus de quorum singulis reperies in hac tabula [...] et de quorum etiam interruptionibus ad invicem infinitae diversitates colorum ad placitum humani ingenii distinguuntur." 
he does not mention any particular set of colors. ${ }^{58}$ Luckily, the framework is filled by the author of the so-called second redaction of Adam's of Buckfield commentary on De sensu et sensato. In it, red (rubeus/puniceus) is put precisely in the middle of the sequence. On its sides, there are, respectively, two colors close to white: lividum and alburgon, and two close to black: viride and kianos. As one may expect, its author, like many thirteenth-century commentators, is not sure of the meaning of the Greek terms, but apparently identifies their designates in a different way than Adam of Buckfield. For him, alburgon cannot stand for "purplish" or "less than purple" (subpuniceum). He claims that subpuniceum is an independent species of color, even if this does not emerge explicitly from Aristotle's text, and as such it should be placed very close to red in the sequence of colors. As a consequence, alburgon loses its meaning proposed by Buckfield: it is deprived of its place close to red in the sequence of colors and thus can no longer be light red, orange or pink. It is placed in the middle between red and white and somewhat surprisingly, identified as "perhaps sky-blue" or "perhaps greenish-blue" (forsan caeruleus). What is more, the term flavum sive lividum known from Buckfield's list is now reduced to lividum, meaning bluish grey alone. As for kianos, the color described as the middle one in the sequence between red and green, we may suspect that it designates violet or, maybe, a color close to today's cyan. ${ }^{59}$ If our interpretation of the meaning of these terms is correct,

${ }^{58}$ Cf. Adam de Whitby, Commentarium in De sensu et sensato Aristotelis, Fi, f. 75vb: "Est autem opinio sua quod sicut duo sunt colores extremi per quorum commixtionem fiunt medii, sic duo sunt sapores extremi per quorum commixtionem fiunt medii et quod colores et sapores medii non excedunt septenarium. Sunt enim duo extremi et quinque medii tam in saporibus quam in coloribus. Ipsorum autem mediorum primus est aeque distans ab extremis ipsis, alii autem quattuor medii sunt inter ipsos extremos et primum medium aequidistantem, duo enim inter unum extremum et primum medium aequidistantem, quorum unus est aequidistans inter extremum et primum medium aequidistantem, alius plus accedens ad primum medium aequidistantem. Non est aliquis plus accedens ad extremum, quia talis diversitas non est notabilis omnino. Similiter sunt duo medii inter reliquum extremum et $<$ medium $>$ aequidistantem primum."

${ }^{59}$ Cf. Ps.-Adam de Buckfield, Expositio in De sensu et sensato Aristotelis, Red. II, V, f. 37ra-rb; E, ff. 155vb-156ra; W, f. 56va: "Puniceus vero color est virtute medius inter album et nigrum qui forte idem est quod rubeus. Alburgon autem est color medius inter puniceum et album, cuiusmodi est forsan caeruleus. Inter album autem et alburgon est lividum quod non ponit in numero cum albo, sed inter alburgon et puniceum est color medius qui subpuniceus dicitur de quo non facit mentionem. Similiter inter puniceum et nigrum est viride directe in medio inter quod et nigrum, licet possit esse alius color medius, 
we get a sequence of colors where yellow is completely absent and there are as many as three hues of blue instead. This seems to corroborate the earlier hypothesis that the early thirteenth-century commentators of De sensu et sensato were interested not so much in hue itself, but rather in the brightness and saturation of a color.

In the spurious third redaction of Buckfield's commentary on De sensu et sensato, kianos (seen probably as deep blue) plays yet another role. The author notices that philosophers disagree which color to call the very middle one, mainly because Aristotle did not specify it, which makes some of them think it is red while others choose other colors of the spectrum, adding offhand that in some books kianos is said to play this role. ${ }^{60}$ This casual remark is extraordinary, since it adds a new contestant for the title of the perfect middle color, i.e., the one with an even ratio between white and black, beside red and green. The candidate was not supported either by philosophers or physicians but, as we know from other sources, it was praised by medieval artists above any other color. For that reason, it is quite probable that our anonymous commentator may have referred to some texts on the art of illuminating manuscripts or some manuals for producing dyes for artistic use.

Such elevation of blue was quite a novelty even in treatises on art at that time, since the growth of its importance dates back to the midtwelfth century and its spread, to the first decades of the thirteenth century. ${ }^{61}$ The process may have been caused by the progress in pigment and dye production, as the artists were finally able to produce beautiful, vibrant and luminous hues of blue rather than the dull and dark tones of the earlier period. ${ }^{62}$ The idea of blue as the middle color did not come from medieval

tamen non ponitur, differens ab extremo propter sui vicinitatem ad extremum. Sed inter viride et puniceum est kianos medius color. Et ita sunt quinque medii et duo extremi."

${ }^{60}$ Cf. Ps.-Adam de Buckfield, Expositio in De sensu et sensato Aristotelis, Red. III, L, f. 133rb-va: "Et sic ex aequali proportione albi et nigri generatur unus color medius, qui dicitur puniceus (puniceus] corr. ex punctus MM), ita quod ex aequali proportione dulcis et amari generatur sapor medius qui dicitur aequidistans. De quo medio $<$ notandum $>$ : eius $<$ color $>$ sic vel alio nomine nominatur, $<$ quia de hoc $>$ non est littera apud philosophos. Et hoc est puniceus enim. Et quidam libri habent in illa parte $<$ puniceum $>$ et alii scilicet hanc litteram $<$ intelligunt aliter $>$ et quod per hoc intelligit $<$ Philosophus $>$ colores alios inter album et nigrum. Aliqui autem libri habent quiannum [...]. Et alii sunt medii inter extremos et colores dictos."

${ }^{61}$ Cf. Pastoureau, 2017, p. 86.

${ }^{62}$ Pastoureau, 2017, p. 86. 
illuminators or painters, however, because they were not interested in setting any sequence of colors ranging from white to black, since they were probably ignorant of Aristotle's teaching on the subject and focused on the beauty and the material value of particular dyes instead. Blue was regarded as the most precious color because it was one of the dyes that was the most difficult to produce. ${ }^{63}$ It was also seen as the strongest color, which meant that if it was mixed with some other paint, it made the whole mixture turn bluish. ${ }^{64}$ The only similarity with Aristotle found in the treatises on painting from the twelfth and thirteenth centuries concerns the division of colors into extreme (white and black) and middle ones. In contrast to Aristotle but in agreement with medical writings, the latter group is divided into seven; this sets the total number of colors at nine: white (album), red (rubeum), green (viride), yellow (croceum), purple (purpureum), deep green (prasinus) ${ }^{65}$, blue $(\text { azur })^{66}$, indigo/violet (indicum), and black (nigrum). ${ }^{67}$ This set, with

${ }^{63}$ Cf. Anonymus, Tractatus qualiter quilibet artificialis color fieri possit (ed. Thompson, 1935, p. 459): "Tractatus qualiter quilibet artificialis color fieri possit atque dupplari, et quomodo unus color misceri cum alio possit, et cognosci valeat, prout scio et ab aliis intellexi et audivi et expertus sum, in hoc opusculo breviter declarabo. Et primo de lazurio, tamquam nobiliori et cariori colore, incipiendum est." There are several recipes in this treatise for producing at least two hues of blue (lazurium citramarinum and lazurium transmarinum).

${ }^{64}$ Another thirteenth-century anonymous treatise on the art of producing paints for artistic use, Florence, Biblioteca Medicea Laurenziana, Plut. 30, cod. 29, f. 72ra, accentuates this feature of blue (azurus): "Fit enim coloratio quae azura vocatur et est nobilior ceteris coloribus inquantum nobilior omnibus, quia superposita aliis coloribus scilicet super omnes colores per se colorantur, quia ad solem quilibet (quaelibet $\mathrm{ms}$.) illuminabitur, quia quod desiccatur numquam color removetur loco. Et si clarificare volueris, ablue aqua, et melius apparebit, et hoc patet super omnes picturas. Nam super pergamenum cum ponatur, oportet ut fiat in tentorio cum illinitur." Cf. Thorndike, 1960, pp. 57-58.

${ }^{65}$ Cf. Jehan le Begue, Tabula de Vocabulis Sinonimis et Equivocis Colorum (ed. Merrifield, 1849, p. 33): "Prasinus est color rubeus; alii dicunt quod habet similitudinem viridis coloris et nigri, sed Catholicon dicit quod prasin Graece, Latine dicitur viridis."

${ }^{66}$ Cf. Jehan le Begue, Tabula de Vocabulis Sinonimis et Equivocis Colorum (ed. Merrifield, 1849, p. 18): “Azurium vel lazurium est color; aliter caelestis vel caelestinus, aliter blauccus, aliter persus, et aliter aethereus dicitur."

${ }^{67}$ Cf. Eraclius, De Coloribus et Artibus Romanorum (ed. Merrifield, 1849, p. 245): "Colorum alii sunt albi, alii nigri, alii sunt medii. Et albi quidem species, caerusa, calx, alumen. Nigri vero, fuscus, et qui ex sarmentis componitur. Medii, rubeus, viridis, croceus, purpureus, prasinus, azur, et indicus; quorum expressio per se cuiuslibet pulchra est, sed interdum sic invicem permixti pulchriores fiunt, quia sua varietate gratiam alter 
its well-identifiable color terms, is clearly better than any proposal found in the thirteenth-century commentaries on De sensu et sensato.

It is tempting to assume that the anonymous author of the so-called third redaction of Adam of Buckfield's commentary knew treatises on painting. Two problems appear here, however. First, the majority of texts on color mixing in his times, numerous as they were, were of Italian or French origin. We know very little of their reception in England, so we cannot say whether he had any chances to consult them. Second, assuming that he had known them, it seems odd that he had not benefited from them more, for a careful reading would have allowed him to replace the enigmatic Greek color names with their Latin equivalents. It is more likely, therefore, that the information about the value of blue reached him by way of personal contact with a professional illuminator. Anyway, we should not disregard this sign of possible influence on philosophers not only by physicians but also by artisans.

The speculation concerning the sequence of colors and the middle color reached its peak in the 1240 s and 1250 s. In the years that followed, the solutions known from the first redaction of Adam of Buckfield's commentary on De sensu et sensato became widely accepted as a sort of via communis doctorum and those problems of the theory of color ceased to be widely discussed. In the late 1250 s or early 1260 s, when Geoffrey of Aspall composed his questions on De sensu et sensato, the fashion for analysing them in detail was seemingly over; only two out of almost 100 questions in his commentary refer to the problem of the sequence of colors and its middle point: ${ }^{68}$ Whether colors are finite or infinite in number ${ }^{69}$ and If we assume that they are infinite, whether all of them can be discerned by our sight. ${ }^{70}$ What is more, even the titles show that Aspall was attracted by other

alteri praestant: Dein compositi aliud monstrant, nam ut in medicinae confectionibus species sibi permixtae invicem conferunt, sic colores non eiusdem qualitatis, ut partem ex alterius natura, partem ex sua trahant, et quam plurimas eorum varietates pulchras et delectabiles reddant, simul commiscentur."

${ }^{68}$ For the list of questions, see Ebbesen, Thomsen Thörnqvist, Decaix, 2016, pp. 66-70.

${ }^{69}$ Galfridus de Aspall, Quaestiones in De sensu et sensato Aristotelis, q. 68, Utrum colores medii sint finiti an infiniti, M, f. 273va; T, f. 117ra-rb.

${ }^{70}$ Galfridus de Aspall, Quaestiones in De sensu et sensato Aristotelis, q. 69, Utrum visus posset ab omnibus coloribus immutari, M, ff. 273vb-274ra; T, f. $117 \mathrm{rb}$. 
aspects of this problem: he switched his interest towards cognitive issues, such as our ability to perceive different colors.

In his commentary, Aspall adopts Averroes's idea that there are seven species of color which have an infinite number of hues; ${ }^{71}$ this statement is also in agreement with Adam of Buckfield's views. ${ }^{72}$ He realizes, however, that even if there is an infinite number of colors in nature, humans are actually able to distinguish—and, supposedly, name-only a limited number of them. ${ }^{73}$ In his solution to the question, he may refer to Buckfield's division of the spectrum once again and states that we can see differences between seven "more notable" colors more clearly than between the infinite number of the "less notable" ones. ${ }^{74}$ Aspall's commentary also provides us with an explanation as to why there are seven colors. He states that there are three pairs of aspects (proprietates) responsible for color

71 See note 31.

${ }^{72}$ Cf. Galfridus de Aspall, Quaestiones in De sensu et sensato Aristotelis, q. 68, Utrum colores medii sint finiti an infiniti, M, f. 273va; T, f. 117ra: "De numero colorum mediorum quaerendum est, et sic intendit Aristoteles generaliter, utrum scilicet sint sub numero finito an infinito. Et videtur quod sub infinito, quia dicit hic Commentator quod colores medii sint infiniti per naturam, et ideo ut dicit ratio extrinseca sive ars non potest super omnes colores super quos potest ratio extrinseca sive natura. Item, Aristoteles dicit hic quod colores medii generantur ex extremis secundum numeralem proportionem, sed numerales proportiones procedunt in infinitum sicut et numerus, quare etc."

${ }^{73}$ Cf. Galfridus de Aspall, Quaestiones in De sensu et sensato Aristotelis, q. 68, Utrum colores medii sint finiti an infiniti, M, f. 273va; T, f. 117ra: "Ad oppositum Aristoteles capitulo de sapore: si sapores essent infiniti, sicut figurae secundum quosdam sunt infinitae, tunc non immutaretur gustus ab istis, eodem modo arguo a parte colorum: si essent infiniti, tunc visus non immutaretur ab aliquo illorum [...]." Cf. Galfridus de Aspall, Quaestiones in De sensu et sensato Aristotelis, q. 69, Utrum visus posset ab omnibus coloribus immutari, M, ff. 273vb-274ra; T, f. 117rb: "Item ad oppositum, visus est virtus corporea operans per instrumentum corporeum, igitur eius potentia limitata est et finita, sed si infiniti colores possent visus immutare, non esset eius potentia limitata immo esset infinita, quare etc."

${ }^{74}$ Cf. Galfridus de Aspall, Quaestiones in De sensu et sensato Aristotelis, q. 69, Utrum visus posset ab omnibus coloribus immutari, M, ff. 273vb-274ra; T, f. 117rb: "Ad ista dico quod ubi sunt contraria extrema et media in extremis est completa distantia specialis, in mediis vero non sed secundum plus et minus. Diversitas etiam specialis incompleta quaedam est magis notabilis, quaedam minus. Cum igitur dicat Aristoteles septem esse species colorum, loquitur de diversitate colorum magis notabili. Completa enim diversitas specialis colorum et incompleta magis notabilis consistit in numero septenari, incompleta tamen diversitas minus notabilis constat in numero infinito." 
variation. The transparent medium in which the coloration takes place can be either pure or impure and the external light can be clear or obscure, concentrated of diffused. When the medium is pure and the external light is clear and concentrated, the color is white. By contrast, an impure and obscure medium, and diffused light produce the color black. ${ }^{75}$ All the remaining colors are also characterised by the three aspects, yet they vary as to the presence or absence of purity (puritas/impuritas perspicui), clarity (claritas/obscuritas lucis) and concentration (multitudo/paucitas lucis).$^{76}$ It is somewhat startling that an application of these criteria produces six rather than five middle colors. Even though Aspall did not mention his source explicitly, the similarity between his view and Robert Grosseteste's theory of colors in his De operatione solis ${ }^{77}$ and De colore $^{78}$ is too strong to be a coincidence. The tacit reference to Grosseteste is both rare and refreshing in the discussion on the number of colors.

With respect to the problem of the middle color par excellence, Aspall declares that neither the Philosopher nor the Commentator admitted the existence of a color in which the proportion of white and black is perfectly even and, following their authority, states that there is little sense in looking for such a color, because either white or black always has to be dominant in the mixture. One can only name a "seemingly middle color" (color quasi medius).${ }^{79}$ For Geoffrey of Aspall, it does not matter which color is considered

75 Cf. Raizman-Kedar, 2007, p. 375.

${ }^{76}$ Cf. Galfridus de Aspall, Quaestiones in De sensu et sensato Aristotelis, q. 69, Utrum visus posset ab omnibus coloribus immutari, M, ff. 273vb-274ra; T, f. 117rb: "Aliter autem accipitur numerus colorum a parte suorum principiorum, scilicet perspicui et lucis. Duae enim sunt proprietates perspicui, scilicet puritas et impuritas, quattuor autem lucis, scilicet claritas et obscuritas, multitudo et paucitas. Secundum autem proportionem illorum proprietatum sunt tantum septem colores, ita quod puritas perspicui cum claritate lucis et multitudine facit albedinem, impuritas autem perspicui cum obscuritate et paucitate lucis facit nigredinem. Et secundum ulteriorem proportionem illarum proprietatum fiunt ceteri colores."

77 Cf. Robertus Grosseteste, De operatione solis, cap. 17 (ed. McEvoy, 1974, p. 78).

${ }^{78}$ Cf. Robertus Grosseteste, De colore (ed. Dinkova-Bruun, 2013, p. 16).

79 Cf. Galfridus de Aspall, Quaestiones in De sensu et sensato Aristotelis, q. 69, Utrum visus posset ab omnibus coloribus immutari, M, ff. 273vb-274ra; T, f. 117rb: "Vel posset dici quod colores procedunt in infinitum materiali diversitate, formali autem diversitate sunt finiti, quia tantum septem, sicut accidit in genere complexionum quod sunt quattuor formales, infiniti vero materiales per declarationem speciei ad esse aliquod. Numerus 
the middle one and, consequently, he does not select any. He is similar to Adam of Whitby in not presenting any concrete sequence of colors. ${ }^{80}$

\section{Conclusion}

\section{A Shift in the Focus of Research after Moerbeke's Revision of the translatio vetus}

The two short questions by Geoffrey of Aspall are the last remarkable contribution to the discussion of colors in the thirteenth-century commentaries on De sensu et sensato in Oxford. Their author not only gathered and synthetized ideas and problems on this subject matter from earlier commentaries and other source texts but also decided which problems were really important and which were only philosophical phantoms without much importance. There were no more questions on the number of colors, or whether they are finite or infinite, or which colors form the sequence of colors and which one is precisely in the middle of it. The lack of any attempts to explain color terminology in the commentaries that followed is surprising if we bear in mind the problems which the first interpreters of Aristotle's De sensu et sensato had with Greek and Latin terms for colors. What is even more puzzling, the explanation for it cannot be attributed to the clarification offered by William's of Moerbeke revision of the anonymous translatio vetus of De sensu et sensato, which was completed in the mid-1260s. An experienced translator of Aristotle's works, such as Moerbeke, would also be expected to

autem colorum sic accipitur: duo sunt extremi, scilicet albedo et nigredo, per quorum commixtionem fiunt medii colores quinque. Si enim commisceantur quasi secundum aequalitatem, faciunt colorem quasi aequidistantem. Et dico 'quasi', quia secundum Aristotelem et Commentatorem impossibile est invenire medium aequidistans ab extremis."

${ }^{80}$ Cf. Galfridus de Aspall, Quaestiones in De sensu et sensato Aristotelis, q. 69, Utrum visus posset ab omnibus coloribus immutari, M, ff. 273vb-274ra; T, f. 117rb: "Si vero dupletur albedo respectu nigredinis, faciunt colorem medium multum propinquum albedini, diversum tamen ab albedine notabili diversitate, et, si plus apponatur de albedine, non erit diversitas notabilis. Similiter si dupletur nigredo respectu albedinis, fiet color propinquus nigredini. Si vero sic commisceantur quod plus sit de albedine, non tamen dupletur albedo, fiet color medius propinquus colori medio quasi aequidistanti, et erit inter colorem quasi aequidistantem et albedinem. Si vero tantum de nigredine respectu albedinis, fiet color medius propinquus colori medio quasi aequidistanti, et erit inter ipsum et nigredinem." 
update the terminology in the translations he corrected. Surprisingly, his version of the passage containing the line of colors goes as follows:

Fere enim aequales humorum species et colorum sunt: septem enim amborum species si quis ponat, sicut rationabile, lividum nigrum aliquid esse; relinquitur enim flavum quidem albi esse sicut unctuosum est dulcis, puniceum vero et alurgon et viride et cyanum in medio albi et nigri. ${ }^{81}$

As can be seen, the changes introduced by Moerbeke are minor and the color terminology is hardly modified. In fact, his only intervention was to make the Greek terms, kianos and alurgon, look more Latin. He changed the ending of cyanos into cyanus, making it possible to decline it according to Latin declension rules. Such a decision may mean that the two terms had already achieved fixed meanings for the Latin users and, for that reason, he felt no need to substitute purely Latin color terms for them, since he could expect that his readers would know their meanings. Nevertheless, his wordchoice contributed to consolidating meanings of these terms in Latin and thus, at least partially, to transmitting cyanus to modern English as cyan.

A side effect of growing popularity of Moerbeke's revision of De sensu et sensato translation in the academic centres of Europe was that scholars no longer blamed their problems with Aristotle's sequence of colors on a bad translation. As a result, doubts started arising about Aristotle's color theory. The scholars found it inconsistent with their everyday experience and gradually stopped trying to save it by all means. The question they asked then was not how Aristotle's theory was to be understood but whether it was correct or not. As a result, all earlier questions were replaced by a single one: whether any middle color can be produced from the mixture of white and black. Moerbeke's revision marked a shift in the focus of research to some other problems and the interpretative tradition of the middle color in the 13th century reached its end.

${ }^{81}$ Cf. Aristoteles, De sensu et sensato, 4 (ed. Leonina, 1985, p. 58; 442a19-25). 


\section{References}

\section{Manuscripts}

Adam de Buckfield. Expositio in De sensu et sensato Aristotelis, Red. I. In:

Madrid, Biblioteca Nacional de España 3314, ff. 100r-110v (Ma);

Milano, Biblioteca Ambrosiana H.105 inf., ff. 1r-18r (Mi);

Oxford, Balliol Coll. 313, ff. 132r-144v (O);

Philadelphia, Free Library, Lewis European 53, ff. 52ra-57vb (Phi).

Ps.-Adam de Buckfield. Expositio in De sensu et sensato Aristotelis, Red. II. In:

Erfurt, Universitätsbibliothek, Dep. Ampl. F. 318, ff. 150r-161r (E);

London, Wellcome Hist. Med. Libr. 3, ff. 53v-60r (W);

Vaticano, Biblioteca Apostolica Vaticana, Vat. lat. 5988, ff. 34ra-41va (V).

Ps.-Adam de Buckfield. Expositio in De sensu et sensato Aristotelis, Red. III. In:

Lisboa, Biblioteca Nacional, Alcobaça 382, ff. 126va-141rb (Li).

Adam de Whitby, Commentum in De sensu et sensato Aristotelis. In:

Firenze, Biblioteca Nazionale Centrale, Conv. Soppr. G 3 464, ff. 73vb-78ra (Fi);

München, Staatsbibliothek, Clm 14522, ff. 149rb-154vb (M);

Paris, BN, lat. 16149, ff. 62ra-67ra (P).

Anonymus. Abbreviationes expositionis in De sensu et sensato Aristotelis Adae de Buckfield. In:

Cambridge, Gonville and Caius College 506 (384), ff. 282r-293r (C);

Erfurt, Universitätsbibliothek, Q. 312, ff. 69va-73vb ( $\left.\mathrm{E}_{2}\right)$.

Galfridus de Aspall. Quaestiones in De sensu et sensato Aristotelis. In:

Cambridge, Gonville and Caius College 509/386, ff. 287ra-302rb;

Oxford, Merton College Library 272, ff. 257ra-276ra;

Oxford, New College 285, ff. 164-189;

Todi, Biblioteca Comunale Lorenzo Leoni 15, ff. 99vb-123ra. 


\section{Primary Sources}

Anonymus (1935). Tractatus qualiter quilibet artificialis color fieri possit. In: D.V. Thompson, Medieval Color-Making: Tractatus Qualiter Quilibet Artificialis Color Fieri Possit from Paris, B. N., MS. latin 6749º . Isis, 22 (2), 456-468.

Anonymus (1973). Problemata, Corpus Christi College, Oxford, 233, ff. 21-31v. In: B. Lawn (ed.), The Salernitan Questions. An Anonymous Collection Dealing with Science and Medicine Written by an Englishman c. 1200, with an Appendix of Ten Related Collections (pp. 326-339). London: The Oxford University Press.

Aristoteles (2016). De sensu et sensato. Ed. L. Peeters, TAGL.13.1, ALDatabase.

Aristoteles (1985). De sensu et sensato. In: Commisio Leonina (ed.), Sentencia libri De sensu et sensato cuius secundus tractatus est De memoria et reminiscencia. Roma-Paris: Commissio Leonina-Libraie Philosophique J. Vrin.

Averroes (1949). In De sensu et sensato. In: A.L. Shields, H. Blumberg (ed.), Averrois Cordubensis Compendia librorum Aristotelis qui Parva Naturalia vocantur (pp. 1-46). Cambridge, MA: The Medieval Academy of America.

Eraclius (1849). De Coloribus et Artibus Romanorum. In: M.P. Merrifield (ed.), Original Treatises Dating from the XIIth to XVIIIth Centuries on the Arts of Painting, vol. 1 (pp. 183-257). London: John Murray, Albemarle Street.

Geoffrey of Aspall (2017). Questions on Aristotle's "Physics". Ed. S. Donati, C. Trifogli. Trans. J. Ashworth, C. Trifogli. Oxford: Oxford University Press.

Jehan le Begue (1849). Tabula de Vocabulis Sinonimis et Equivocis Colorum. In: M.P. Merrifield (ed.), Original Treatises Dating from the XIIth to XVIIIth Centuries on the Arts of Painting, vol. 1 (pp. 18-38). London: Albemarle Street.

Robertus Grosseteste (2013). De colore. In: G. Dinkova-Bruun, G.E.M. Gasper, M. Huxtable, T.C.B. McLeish, C. Panti, H. Smithson (ed.), The Dimensions of Colour. Robert Grosseteste's De colore. Durham-Toronto: Pontifical Institute of Medieval Studies.

Robertus Grosseteste (1974). De operatione solis. In: J. McEvoy, The Sun as res and signum: Grosseteste's Commentary on »Ecclesiasticus« ch. 43, vv. 1-5. Recherches de théologie ancienne et médiévale, 41, 38-91.

Roger Bacon (1902). Grammatica Graeca. In: E. Nolan, S.A. Hirsch (ed.), The Greek Grammar of Roger Bacon and a Fragment of His Hebrew Grammar, Cambridge: Leopold Classic Library.

Roger Bacon (1937). Liber De sensu et sensato. In: R. Steele (ed.), Opera hactenus inedita Rogeri Baconi, fasc. 14. Oxonii: E Typographeo Claredoniano. 
Roger Bacon (1897). Opus Maius. In: J.H. Bridges (ed.), The “Opus Majus” of Roger Bacon, vol. 1, London: Cambridge University Press.

\section{Secondary Sources}

Bloch, D. (2008). Nicolaus Graecus and the Translatio Vetus of Aristotle's "De Sensu." Bulletin de Philosophie Médiévale, 50, 83-103.

Bradley, M. (2009). Colour and Meaning in Ancient Rome. Cambridge: Cambridge University Press.

Brewer, J.S. (1858). Monumenta Franciscana. Vol. 1. London: Longman.

Callus, D.A. (1943). Introduction of Aristotelian Learning to Oxford. In: The British Academy (ed.), Proceedings of the British Academy, vol. 29 (pp. 1-55). London: Geoffrey Cumberlege.

Callus, D.A. (1952). The Powers of the Soul. An Early Unpublished Text. Recherches de Théologie ancienne et médiévale, 19, 131-170.

Dod, B.G. (2008). Aristoteles Latinus. In: N. Kretzmann, A. Kenny, J. Pinborg (eds.), The Cambridge History of Later Medieval Philosophy (pp. 45-79). Cambridge: Cambridge University Press.

Ebbesen, S., Thomsen Thörnqvist, Ch., Decaix, V. (2016). Questions on "De sensu et sensato," "De memoria" and "De somno et vigilia": A Catalogue. Bulletin de Philosophie Médiévale, 57, 59-115.

Eco, U. (1985). How Culture Conditions the Colours We See. In: M. Blonsky (ed.), On Signs: A Semiotic Reader (pp. 157-175). Oxford: Blackwell.

Emden, A.B. (1957). A Biographical Register of the University of Oxford to A.D. 1500. Vol. 1. Oxford: Oxford Clarendon Press.

Galle, G. (2008a). Edition and Discussion of the Oxford Gloss on "De sensu 1." Archives d'histoire doctrinale et littéraire du Moyen Âge, 75, 197-281.

Galle, G. (2008b). The Anonymous Translator of the "Translatio Vetus" of "De Sensu." Bulletin de Philosophie Médiévale, 50, 105-150.

Köhler, T.W. (2017). Homo animal nobilissimum: Konturen des Spezifisch Menschlichen in der Naturphilosophischen Aristoteleskommentierung des Dreizehnten Jahrhunderts. Vol. 1. Leuven: Brill.

Lewis, Ch.T., Short, Ch. (1879). A Latin Dictionary. Founded on Andrews' Edition of Freund's Latin Dictionary. Oxford: Clarendon Press. 
Lohr, C.H. (1967). Medieval Latin Aristotle Commentaries: Authors A-F. Traditio, 23, 313-413.

Lohr, C.H. (2013). Latin Aristotle Commentaries I.1 Medieval Authors A-L. Firenze: Sismel Edizioni del Galluzzo.

Noone, T.B. (1992). Evidence for the Use of Adam of Buckfield's Writings at Paris: A Note on New Haven, Yale University, Historical-Medical Library 12. Mediaeval Studies, 54, 308-316.

Parkhurst, C. (1990). Roger Bacon on Color: Sources, Theories and Influence. In: K.-L. Selig, E. Sears (eds.), The Verbal and the Visual, Essays in Honor of William Sebastian Heckscher (pp. 151-202). New York: Italica Press.

Pastoureau, M. (2017). Red: The History of a Colour. Princeton-Oxford: Princeton University Press.

Pastoureau, M. (2018). Blue: The History of a Colour. Princeton-Oxford: Princeton University Press.

Raizman-Kedar, Y. (2007). Questioning Aristotle: Roger Bacon on the True Essence of Colour. Journal of Medieval Latin, 17, 372-383.

Russell, J.C. (1936). Dictionary of Writers of Thirteenth Century England. London: Longmans, Green.

Steele, R. (1937). Introduction. In: R. Steele (ed.), Opera hactenus inedita Rogeri Baconi, fasc. 14 (pp. v-xvi). Oxonii: E Typographeo Claredoniano.

Thomson, S.H. (1944). A Note on the Works of Magister Adam de Bocfeld (Bochermefort). Medievalia et Humanistica, 2, 55-87.

Thomson, S.H. (1958). A Further Note on Master Adam of Bocfeld. Medievalia et Humanistica, 12, 23-32.

Thorndike, L. (1960). Other Texts on Colours. Ambix, 8 (2), 53-70.

Weijers, O. (1994). Le travail intellectuel à la Faculté des arts de Paris: textes et maîtres (ca. 1200-1500), I. Répertoire des noms commençant par A-B. Turnhout: Brepols. 


\begin{abstract}
The intersections between philology and philosophy are visible in the interpretations of passages of Aristotle's De sensu et sensato devoted to the so-called middle color (color medius) by several philosophers active in Oxford in the middle of the thirteenth century, such as Adam of Buckfield, Adam of Whitby and Geoffrey of Aspall. In their work, they had to struggle not only with problems originating from De sensu et sensato itself, but also with others caused by the poor quality of its only translation available at that time. They also discussed a new philosophical problem emerging from Aristotle's text: if there is a sequence of colors stretched between white and black, where middle colors are evenly distributed throughout it according to the ratio of whiteness and blackness in each of them, there must be a color in which the ratio is perfectly even and, therefore, it has to occupy the position in the very middle of the sequence. My paper presents their search for the middle color par excellence and intense discussions on the nature of the middle color.
\end{abstract}

